custom in Domesday Book when any place is an island, to call it so. For example, in vol. i., folio 75, "Dorsete" [Dorset], we have-" The land of the King. The King holds the island which is called Poriand [i.e. Portland]. King Edward held it in his life." And again, same vol., fol. 396-"Hanteschire [i.e. Hampshire]. These lands below written lie in the isle of Wit" [i.e. Wight].

In short, the Mount could not have been an island in 1086, because it then contained at least eight times as much land as it does at present, probably connecting it with the mainland, from which it is even now only one-third mile distant. The truth, Sir Henry Ellis says, seems to be that a hide, a yardland, a knight's fee, \&c., contained no certain number of acres, but varied in different places at different times. He siys there are "four virgates in each hide, and thirty acres to make a virgate." The elementary acre was 40 perches by 4 perches, as now. $\Lambda$ nd, accordingly, the 8 carucates would amount to the respective numbers of acres mentioned in the last column of the following table at the respective times:-

\begin{tabular}{|c|c|c|c|}
\hline Periods & $\begin{array}{r}\text { Acres in a } \\
\text { Carucate }\end{array}$ & $\begin{array}{l}\text { No. of } \\
\text { Carucates }\end{array}$ & $\begin{array}{l}\text { Total } \\
\text { Acres }\end{array}$ \\
\hline e temp. Richard I. & 60 & & 480 \\
\hline & 100 & 8 & 800 \\
\hline Edward $\mathrm{I}$. & 180 & 8 & 1440 \\
\hline vard III. 1O & n) 112 & 8 & 896 \\
\hline Middleton & on 150 & 8 & I 200 \\
\hline
\end{tabular}

The hide is generally supposed to have been $x 20$ acres. Now, taking the smallest of these measures, we shall have for the two hides 240 acres. The present area of the Mount, however, is only 30 acres, so that there are 210 acres missing. How can we account for them except by supposing that the Mount extended further, perhaps in every direction? The hide of land taken by Earl Moriton was given to Mont S. Michel, * on the lirench coast where Normandy joins Britanny, in 1085 .

I have before me "Two of the Saxon Chronicles parallel," edited and commented on by the Rev. John Earle, formerly Professor of Anglo-Saxon, Oxford, from which the two following remarkable passages are extracted for the respective years $1_{0}{ }_{4}$ and rog9.

" 1 ,or4. And on this year, on Saint Michael's-Mass-Even, came that great sea-flood through widely this land, and ran so far up as never before not did, and submerged many towns, and mankind innumerable number," p. I $5 \mathrm{r}$.

"1,099. This year also, on st. Martin-Mass-Day, sprang up that exceeding sea-flood, and so much to harm dicl, as no man not remembered that it ever afore did, and was that same day a new moon," p. 235.

Nobody seems to contend that the coasts of Cornwall have simply been abraded ard cut back by the action of the sea during the Christian period. Nor does anyone appear to doubt that there has been a subsidence. Now there are 2ro acres of land missing since 1086 , and in 1009 , thirteen years after, we have a record of a catastrophe which would fully account for the loss! Supposing, whilst travelling in a foreign country, we were to come suddenly upon a city in ruins, when we had personally experienced shocks of earthnuake a short time before. How could we doubt that the earthquake was the cause of the ruius, and how can we doubt that the remarkable event of 1099 caused the loss of land by subsidence and the Insulation of the Mount?

Sir Henry de la Beche (Report on Cornwall, \&c., p. 417, et seg.) says "submarine forests are so common that it is difficult not to find traces of them in the district at the mouths of all the numerous valleys which open upon the sea, and are in any manner silted up." . . . . It is well known that abundance of roots and stumps of trees have been found in situ for some distance on the south of the Mount. And no one seems to doubt that "the Mount was formerly five or six miles from the sea, and enclosed with a very thick wood," and that it was called in the Cornish language "the hoar rock in the wood,"

I have before me the very interesting Prize Essay by Mr. John E. Thomas, F.G.S., written for the National Eisteddfod, held at Chester, 1866, upon the "Encroachment of the Sea between the River Mersey and the Bristol Channel." † Prof. Ramsay, who bad the adjudication of the prize, says, "The result is so who has the prize of $\mathrm{iol}$. and a medal." Mr. Thomas does not look furtiner back than the year 520 for his sinkings in Cardigan Bay (p. 13). A

- Penny Cyclop. Art. Cornwalt.

+ Publinhed by Msssss, Spon, Charing Cross, price sso perusal of the whole tract of twenty-four pages will well repay gentlemen who take an interest in this particular department of geology.

Jersey, Jan. 23

R. A. PeAcock

\section{Measurement of Mass}

Prof. EveretT's first letter contains the statement " Deschanel, in accordance with what has been till recent years an almost universal custom, employs a variable unit of force, and as depending upon this, a variable unit of mass, so that the number denoting the mass of one and the same body is diminished as the body is carried from the equator to the poles, and would increase up to infinity if the body fell to the centre of the earth."

I wished to point out that in making the standard pound a unit of force, by defining the place where it is to be used, we do not adopt a unit of mass which is variable, since if we take three times as much matter as gravitates with the unit force, we shall obtain the same mass at whatever point of the earth's surface the comparison is made. I camnot see that the adoption of this method necessitates any filing or loading of weights to suit change of latitude, since we invariably employ an ordinary balance and not a spring balance to effect our weighings.

Whenever it does become necessary to compare gravitating forces, we are obliged to fall back upon the use of the pendulum, whether we adopt the old system of standards or the new.

As a philosophical theory I am perfectly ready to admit that the standard pound is most appropriately considered as a standard of mass, but the employment of this standard in a text-book for the use of beginners seems calculated to lead to confusion.

If we refuse to commit ourselves to the absurdity of comparing the quantity of one kind of matter with the quantity of another kind of matter, I hardly see how mass is to be defined except by means of weight, and without, for the moment at least, em. ploying weights as measures of force.

The assumption of a hypothetical force of gravity not dependent on latitude seems to stand on the same footing as the employment of a mean solur day; it is convenient, leads to no confusion, and is not unphilosophical.

W. M. W.

\section{Mount Etna}

IT may interest the observers who have lately been in Sicily to hear that since their departure there has been a sad falling off in the appearance of Etra. The grand wreath of steam that used to $10 l l$ out of the cratcr at such stately leisure that you could hardiy detect any movement without close attention, suddenly ceased about three days ago, and left nothing more than a tiny wisp of smoke, rather suggestive of a cottage chimney than a volcano. I call it smoke because the coluur becane decidedly darker than it used to be, and the manner of its dissipation is different. Formerly, after issuing from the crater it used to assume true cloud forms, and lie about the mountain exactly like clouds: now, it diffuses itself as a thin veil over the sky; sometimes heing traceable in a streak as far as the coast of Calabria. Its volume is perhaps a thousandth part of what it was last week. It issues in a distinctly spiral form, the wreath oscillating apparently from side to side of the crater; and sometimes there are little puffs of extra size, whilst at others the wreath is nearly sundered.

The date of the change cannot be very precisely given, although I have watched the mountain at all hours of the day for a week past, in hopes of getting a correct outline of it for pictorial purposes. The clouds only cleared off completely yesterday; but I observed that a change in the wreath had taken place as early as Friday the $13^{\text {th }}$ January. The weather up to the $15^{\text {th }}$ has been outrageously squally and rainy, but is now superb. Last night there was a magnificent display of zodiacal light, considerably brighter than we saw it at Augusta before the Eclipse, and distinctly traceable up to the zenith; the apex of the cone reaching to within about $10^{\circ}$ of the Pleiades. It was brightest about 7 P.M., but was still visible at Io P.M., when clouds shut it out.

Taornina, Sicily, Jan. I7

JOHN BRETT

\section{Note on Chromosphere Lines}

A VERY small but very bright prominence on the N.W. limb of the sun, observed at Xeres Dec. 21st, gave in addition to the ordinary protuberance bright lines the following-one below $\mathrm{C}$ 